\title{
FORESTRY
}

DOI https://doi.org/10.30525/978-9934-26-184-8-15

\section{ФОРМУВАННЯ У ФАХІВЦІВ НАВИЧОК ДОСЛІДЖЕННЯ ТА ЗБЕРЕЖЕННЯ БІОРІЗНОМАНІТТЯ НА ТЕРИТОРЇ̈ ДП «СОЛОТВИНСЬКЕ ЛІСОВЕ ГОСПОДАРСТВО»}

\author{
Карбівська У. М. \\ доктор сільськогосподарських наук, дочент, \\ професор кафедри лісового і аграрного менеджменту \\ факультету природничих наук \\ ДВНЗ «Прикарпатський національний університет \\ імені Василя Стефаника» \\ Григорів Я. Я. \\ кандидат сільськогосподарських наук, \\ викладач кафедри лісового і аграрного менеджменту \\ факультету природничих наук \\ ДВНЗ «Прикарпатський національний університет \\ імені Василя Стефаника»
}

\section{Гудима В. М. \\ кандидат сільськогосподарських наук, вчений секретар}

Украӥнський науково-дослідний інститут гірського лісівництва імені П. С. Пастернака м. Івано-Франківськ, Україна

На сучасному етапі розвитку людства першочерговим завданням постає збереження біорізноманіття планети, в тому числі як рослинного різноманіття в цілому, так і генетичних ресурсів лісів - одного 3 основних його компонентів. Термін «біологічне різноманіття» запропонований Томасом Лавджоєм 
(Thomas Lovejoy) у 1980 р., a біорізноманіття - вперше прозвучало від Едварда Вілсона (Edward Wilson) у 1986 р., у доповіді на першому Американському форумі з біологічного різноманіття, організованому Національною Радою Досліджень (NRC, National Research Council). Відтоді це слово одержало значне поширення, а під біорізноманіттям розуміють варіативність життя на всіх рівнях біологічної організації (різноманітність живої природи), або як міру відносного різноманіття серед сукупності організмів, що входять до деякої екосистеми. Таке різноманіття позначає як відмінності всередині видів, так і між видами, між родами, родинами і навіть екосистемами. Найбільш детально це питання обговорювалося в 1992 році на конференції ООН в Ріо-деЖанейро, де якраз і було прийнято Конвенцію про охорону біологічного різноманіття [1, с. 3].

Науковці стверджують, що флористичне біорізноманіття України нараховує понад 25 тисяч видів рослин. Зараз прийнято говорити про три рівні біорізноманіття: генетичний, видовий та різноманітність екосистем. Особливої уваги вивченню флористичного та фауністичного біорізноманіття в різних країнах світу, в тому числі і в Україні, приділяють наукові установи природоохоронного профілю, які досліджують біорізноманіття цілих регіонів та екосистем, а також національні природні парки, заповідники, заказники, ботанічні сади і дендропарки [2, с.4]. Дослідження та збереження біорізноманіття $\epsilon$ важливим у формуванні здобувачів вищої освіти першого (бакалаврського) та другого (магістерського) рівня спеціальності 205 Лісове господарство, практичних навичок для застосування у цій сфері.

Біорізноманіття, яке ми бачимо сьогодні - це продукт еволюції життя впродовж мільярдів років, який визначається природними процесами, і на який все більше впливає людська діяльність. Це тканина життя, складовою частиною якої $є$ ми і від якої ми повністю залежимо. Для людей біорізноманіття має економічну, рекреаційну, культурну, екологічну та інші цінності. Наше власне здоров'я, а також здоров'я економіки та суспільства в цілому залежить від безперервного отримання різноманітних «екосистемних послуг», замінити які буде або дуже дорого, або просто неможливо, тобто тих вигод, які людство отримує від 66 
екосистем. Це послуги екосистем із забезпечення людства природними ресурсами, здоровим середовищем існування, іншими екологічно та економічно значущими «продуктами» [3, c. 119].

Загальна площа держлісфонду ДП «Солотвинське ЛГ» становить 20,8 тис. га. Розподіл за категоріями лісів вказує на переважання експлуатаційних лісів (74\%), трохи меншу територію займають рекреаційно-оздоровчі ліси (13\%), площа лісів природоохоронного, наукового та історико-культурного призначення становить $7 \%$, захисних $-5 \%$.

У лісах природоохоронного, наукового та історико-культурного призначення найбільшу площу займають заказники (992 га), майже в два рази менше - заповідні лісові урочища (507 га), ліси наукового призначення, включаючи генетичні резервати - 80,4 га i найменшою $\epsilon$ площа, зайнята пам'ятками природи $(3,1$ га). Стосовно рекреаційно-оздоровчих лісів, найбільшу територію займає тут лісогосподарська частина лісів зелених зон (1825,0 га). Приблизно в два рази меншу територію займає лісопаркова частина лісів зелених зон (875 га) і зовсім мало підкатегорія лісів 3 зони округів санітарної охорони лікувально-оздоровчих територій (68 га).

Розподіл захисних лісів за підкатегоріями свідчить про переважання протиерозійних лісів (688,0 га). Ліси вздовж берегів річок, навколо озер, водойм займають територію площею 351 га, ліси вздовж смуг відведення автомобільних доріг - 5 га. На даній території переважаючими є такі лісотвірні породи: ялина європейська (6,5 тис. га), ялиця біла (4,6 тис. га) і бук лісовй $(5,4$ тис. га). Розподіл порід у межах категорій земель буде наступним. Переважаючими породами у заказниках $є$ ялина європейська, ялиця біла та бук лісовий. У заповідних лісових урочищах найбільше ялини європейської. Дещо менше тут бука лісового і ялиці білої. Щодо лісів наукового призначення, включаючи генетичні резервати найбільше у кількісному відношення у них букалісового. Породний склад пам'яток природи складають сосна звичайна реліктова та ялиця біла $(2,1$ і 1,0 га відповідно). 
У лісогосподарській частині лісів зелених зон найбільше дуба звичайного, ялини європейської, бука лісового, дуба червоного та ялиці білої. Рідко у лісах цієї підкатегорії зустрічаються ясен звичайний, явір i сосна кедрова європейська (менше 1 га). Найпоширенішим видом у лісопарковій частині лісів зелених зон $€$ дуб звичайний. Найменш поширеним - бук лісовий. У лісах 3 зони округів санітарної охорони лікувально-оздоровчих територій практично всю територію займає дуб звичайний. Найменш поширеною на цих територіях є осика.

У лісах вздовж берегів річок, навколо озер, водойм та ін. майже одинакові площі займають ялина європейська та ялиця біла. Дещо менше тут бука лісового і найменше на цих територіях осики. Значну територію протиерозійних лісів складає ялина європейська. Ялиця біла та бук лісовий займають територію 94,4 i 72,4 га відповідно. У лісах вздовж смуг відведення автомобільних доріг найбільш розповсюджена ялиця біла. Майже в три рази менше у них ялини європейської. Незначні території займають сосна звичайна реліктова і дуб звичайний.

Тип лісорослинних умов є важливим лісівничим показником, який характеризує однорідні лісорослинні умови на вкритих i невкритих лісовою рослинністю лісових ділянках. Для їхньої класифікації використовується едафічна сітка АлексєєваПогребняка, побудована на основі вологості та багатства грунту. На території ДП «Солотвинське ЛГ» найбільш розповсюдженими $\epsilon$ вологі сугруди $\left(\mathrm{C}_{3}\right)$, які поширюються на території 14931 га. Другими за площею поширення є сирі сугруди $\left(\mathrm{C}_{4}\right)$, ïx площа становить 2177,5 га, загальна площа вологих грудів $\left(\mathrm{D}_{3}\right)$ становить 1878 га. Вологі субори $\left(\mathrm{B}_{3}\right)$ на території лісгоспу займають 543 га і зосереджені, в основному, у лісах природоохоронного, наукового, історико-культурного призначення - на території заказників i заповідних лісових урочищ та протиерозійних лісах (119,5 га). Решту типів лісорослинних умов (А3, А4, В2, Д2, Д4) представлені невеликими площами.

Розподіл за типами лісу свідчить про переважання у держлісфонді підприємства вологих буково-смерекових суяличин (7539 га), близько 3,5 тис. га замають насадження вологих смереково-ялицевих субучин, ще майже по 800 га займають 68 
насадження вологих буково-смерекових яличин та смерековоялицевих бучин. Понад 2 тис. га займають сирі смерекові яличини і понад 700 га вологі буково-ялицеві сусмеречини. В цілому, слід відзначити що типологічна структура держлісфонду складається iз близько 50 типів лісу, але переважають на території підприємства змішані буково-смереково-ялицеві насадження.

На території дослідження збереженню та ренатуралізації в першу чергу підлягають види, які ще збереглись в лісових масивах, окремих населених пунктах та розташованому на території лісгоспу дендропарку «Діброва» тощо. Їх наявність слугує доброю репродуктивною базою, i сприяє в подальшому їх розширенню та участі в лісових насадженнях та озелененні. До таких видів слід віднести наступні аборигенні породи: Сосна кедрова європейська (Pinus cembra L.), Сосна звичайна карпатського екотипу реліктова (Pinus silvestris L.), Тис ягідний (Taxus baccata L.), Модрина польська (Larix Polonica L.), Клокичка периста (Staphylaea pinnata L.), Берека глоговина (Sorbus torminalis L), Горобина домашня (Sorbus domestica L).

Встановлено значну роль ДП «Солотвинське лісове господарство» у збереженні фітогено- та фітоценофонду на регіональному й державному рівні. Зокрема, виявлено 15 видів судинних рослин, включених до «Червоної книги України», установлено 5 рослинних асоціацій, які включені до «Зеленої книги України», а також - 11 регіонально рідкісних видів рослин. Вивчення раритетної складової рослинного покриву підприємства 3 метою охорони та збереження як фітогено-, так і фітоценорізноманіття Карпатського регіону є невід'ємною умовою для збереження раритетного фіторізноманіття Івано- Франківської області зокрема та України загалом.

\section{Література:}

1. Загороднюк I.M. Основи диверсикології: зміст лекцій для спеціальності «Екологія». Ужгород: УжНУ, 2004. 20 с.

2. Біорізноманіття Карпатського біосферного заповідника. Центр впровадження міжнародних екологічних програм «ІнтерЕкоЦентр» ред. Я.І. Мовчан. Київ, 1997. 711 с. 
3. Bila A., Lindgren D. Fertility variation in Milletias tuhlmannii, Brachystegia spiciformis, Brachystegia bohemii and Leucaena leucocephala and ist effects on relatedness in seeds. Forest genetics. 1998. Vol. 5 (2). P. 119-129.

DOI https://doi.org/10.30525/978-9934-26-184-8-16

\title{
СТАЦІОНАРНІ ДОСЛІДЖЕННЯ РУБОК ДОГЛЯДУ В СОСНОВИХ ДЕРЕВОСТАНАХ
}

\author{
Лавний В. В. \\ доктор сільськогосподарських наук, професор, \\ професор кафедри лісівництва \\ Національний лісотехнічний університет Украӥни \\ м. Львів, Україна \\ Петер Шпатгельф \\ професор факультету лісу і довкілля \\ Університет сталого розвитку Еберсвальде \\ м. Еберсвальде, Німеччина \\ Вицега Р. В. \\ кандидат сільськогосподарських наук, доиент, \\ дочент кафедри лісової таксації та лісовпорядкування \\ Національний лісотехнічний університет України \\ м. Львів, Україна
}

Формування біологічно стійких та високопродуктивних деревостанів вимагає своєчасного проведення в них лісогосподарських заходів, зокрема рубок догляду. Сучасні нормативи не повною мірою регламентують основні критерії щодо проведення рубок формування та оздоровлення лісів і не завжди враховують особливості окремого деревостану. Удосконалення нормативної бази вимагає сучасних глибоких наукових досліджень 3 70 